\title{
Pengaruh Green Product dan Green Price Terhadap Minat Beli Konsumen Pada Produk Tupperware (Studi Kasus Pada Mahasiswa Manajemen FE UNISLA)
}

\author{
Rivatul Ridho Elvierayani ${ }^{1 *}$, Fisati Choiroh ${ }^{2}$ \\ 1,2 Manajemen, FE, Universitas Islam Lamongan \\ *email: rivatulridho@unisla.ac.id
}

\begin{abstract}
Plastic has become a part of human daily life. Its non-recyclable nature makes many questions arise about safe plastic used as a container for food and drinks. So many consumers are interested in buying products made from plastic that are safe for health and friendly to the environment. This study aims to analyze and discuss the effect of green products and green prices on consumer buying interest in tupperware products (case study in Management students of the Faculty of Economics, Lamongan Islamic University). The research method used is quantitative research. The sample used is nonprobability sampling with a purposive sampling technique with a total of 100 respondents. Data analysis used was validity, reliability, classic assumption test and multiple linear regression using SPSS 20. Mathematics models for the influence between green products and green prices on Tupperware products is $Y=2,997+0,548 X_{1}+0,164 X_{2}$. The results showed that there was a positive influence between green products and green prices on Tupperware products on buying interest of Lamongan Islamic University management students. The results of the coefficient of determination $\left(R^{2}\right)$ of 0.332 , meaning that green products and green prices contribute to influence consumer buying interest by $33.2 \%$ while the remaining $66.8 \%$ is influenced by other variables outside the variables studied by researchers. Keywords: green marketing, green product, green price, custumers purchase intention
\end{abstract}

\begin{abstract}
Abstrak
Plastik sudah menjadi bagian keseharian manusia. Sifatnya yang tidak bisa didaur ulang menjadikan banyak pertanyaan yang muncul seputar plastik yang aman digunakan sebagai wadah untuk makanan dan minuman. Sehingga banyak konsumen yang tertarik untuk membeli produk berbahan plastik yang aman bagi kesehatan maupun ramah terhadap lingkungan. Penelitian ini bertujuan untuk menganalis dan membahas pengaruh green product dan green price terhadap minat beli konsumen pada produk tupperware (studi kasus pada mahasiswa Manajemen Fakultas Ekonomi Universitas Islam Lamongan). Metode penelitian yang digunakan adalah penelitian kuantitatif. Sample yang digunakan merupakan nonprobability sampling dengan teknik purposive sampling dengan jumlah 100 responden. Analisis data yang digunakan adalah validitas, reliabilitas, uji asumsi klasik dan regresi linear berganda dengan menggunakan software 20 SPSS Model matematika diperoleh $Y=2,997+0,548 X_{1}+0,164 X_{2}$ sebagai representasi pengaruh green product dan green price terhadap minat beli konsumen pada produk Tupperware. Hasil penelitian menunjukkan bahwa ada pengaruh positif antara green product dan green price pada produk tupperware terhadap minat beli mahasiswa manajemen Universitas Islam lamongan. Hasil nilai koefisien determinasi $\left(R^{2}\right)$ sebesar 0,332 , artinya green product dan green price berkontribusi mempengaruhi minat beli konsumen sebesar 33,2\% sedangkan sisanya sebesar $66,8 \%$ dipengaruhi oleh variabel lain di luar variabel yang diteliti oleh peneliti.
\end{abstract}

Kata Kunci: green marketing, green product, green price, minat beli

\section{PENDAHULUAN}

Masalah kepedulian akan lingkungan dan kesehatan saat ini telah menjadi isu sentral disemua kalangan dan telah merubah cara pandang dan pola hidup masyarakat 


\section{Mandalika Mathematics and Education Journal \\ Volume 2 Nomor 1, Juni 2020 \\ e-ISSN 2715-1190 | | p-ISSN 2715-8292 \\ DOI: http://dx.doi.org/10.29303/mandalika.v2i1.1751}

Indonesia. Pandangan tersebut merupakan pandangan baru dalam kehidupan masyarakat yang dikenal dengan eco green. Dengan maraknya isu-isu tentang pencemaran lingkungan, maka banyak perusahaan yang menerapkan sistem eco-green dalam strategi pemasarannya untuk menarik daya beli masyarakat. Kesadaran masyarakat terhadap produk hijau menjadikan perusahaan menerapkan isu-isu lingkungan sebagai salah satu strategi pemasarannya agar eksis dan dikenal sebagai pemasaran hijau (green marketing). Menurut pendapat Dahlstrom (2011), green marketing merupakan studi dari semua upayadalam kegiatan konsumsi, produksi, distribusi, promosi, serta pengemasan produk sebagai respon keprihatinan terhadap lingkungan. Dalam green marketing terdapat proses perencanaan dan pelaksanaan bauran pemasaran untuk memfasilitasi reklamasi konsumsi, produksi, distribusi, promosi, pengemasan, dan produk sebagai bentuk keprihatinan terhadap lingkungan.

Kondisi alam yang mengalami perubahan iklim berdampak pada perubahan kondisi lingkungan yang diakibatkan oleh pola kegiatan manusia yang tidak peka terhadap masalah lingkungan sehingga menjadikan lingkungan tercemar oleh sampah-sampah produk yang tidak bisa didaur ulang secara langsung. Salah satu sampah yang sulit didaur ulang adalah plastik. Plastik sudah menjadi bagian keseharian manusia, desain kemasannya yang menarik serta fungsinya yang serba guna menjadi salah satu alasan mengapa plastik digemari masyarakat. Namun banyak pertanyaan yang muncul seputar plastik yang aman yang digunakan sebagai wadah untuk makanan dan minuman. Sebagai salah satu alternatif adalah menggunakan produk yang ramah lingkungan atau bisa disebut green product. Menurut Polonsky, dkk (2002) Green product adalah upaya untuk meminimalkan limbah ketika proses produksi di samping memaksimalkan produk yang dibuat sekaligus memenuhi syarat ramah lingkungan. Green product sendiri harus mempunyai kualitas produk yang tahan lama, dalam artian tidak mudah rusak, tidak mengandung racun, dibuat dari bahan yang dapat di daur ulang dan memiliki packaging yang minimalis.

Proses keputusan konsumen dalam menentukan produk yang akan mereka beli diperngaruhi oleh tiga faktor utama yaitu (1) strategi pemasaran, (2) perbedaan individu, (3) faktor lingkungan. Sehingga bentuk strategi pemasaran seperti green marketing (termasuk di dalamnya green product) dapat menimbulkan minat beli konsumen pada suatu produk. Karena minat beli meupakan tahapan awal konsumen dalam menentukan keputusan pembelian (Sumarwan, 2011).

Harga merupakan elemen penting dalam pemasaran. Harga dapat membentuk persepsi konsumen terhadap kualitas suatu produk. Banyak konsumen yang rela membayar dengan harga premium untuk suatu produk ketika mereka memiliki persepsi tambahan terhadap nilai produk. Peningkatan nilai ini dapat disebabkan oleh kinerja, fungsi, 


\section{Mandalika Mathematics and Education Journal \\ Volume 2 Nomor 1, Juni 2020 \\ e-ISSN 2715-1190 | | p-ISSN 2715-8292 \\ DOI: http://dx.doi.org/10.29303/mandalika.v2i1.1751}

desain, bentuk yang menarik atau kecocokan selera (Haryadi, 2009). Kualitas produk dalamhal ini ditentukan pada pengukuran kualitas objektif dan kualitas yang dipersepsikan. Kualitas objektif (objective quality) didefinisikan sebagai atribut yang dapat diukur dan dikuantifikasikan dari dalam produk dibandingkan dengan produk standard yang dapat dibuat. Sedangkan persepsi kualitas (perceived quality) didefinisikan sebagai keputusan konsumen tentang superioritas dari suatu produk (Zaithami dalam Haryadi, 2009).

Dengan meningkatnya kesadaran masyarakat terhadap produk ramah lingkungan dan memperhatikan aspek kesehatan, banyak perusahaan-perusahaan nasional maupun multinasional yang menerapkan green marketing dalam kegiatan pemasaran produknya. Salah satu perusahaan yang melakukan strategi pemasaran dengan gaya ini adalah perusahaan Tupperware Brands Corporation. Sebagai alternatif produk ramah lingkungan. Tupperware adalah nama merek terkenal dari peralatan rumah tangga yang terbuat dari plastik, termasuk didalamnya, wadah penyimpanan, wadah penyajian dan beberapa peralatan dapur. Dalam hal ini produk Tupperware yang dilihat dari elemenelemen green marketing (termasuk di dalamnya green product) dapat mempengaruhi konsumen untuk melakukan pembelian.

Selain dilihat dari elemen-elemen green marketing, tupperware mempunyai daya tarik melalui desain yang menarik dan sesuai dengan kebutuhan sehari-hari serta efisien dalam penggunaanya sehingga dapat digunakan oleh semua kalangan,tidak terkecuali kalangan mahasiswa. Berdasarkan survey yang dilakukan oleh peneliti rata-rata mahasiswa Universitas Islam Lamongan membawa botol minum ataupun wadah makan merk Tupperware untuk bekal di kampus. Melambungnya brand tupperware ini membuat mahasiswa Universitas Islam Lamongan juga menggunakannya sesuai dengan tingkat kebutuhan mereka.

Berdasarkan hasil ulasan tersebut, tujuan dari penelitian ini adalah untuk menganalisis dan membahas pengaruh green product dan green price pada produk tupperware terhadap minat beli konsumen (studi kasus pada mahasiswa Manajemen Fakultas Ekonomi Universitas Islam Lamongan).

\section{METODE}

Penelitian ini merupakan penelitian kuantitatif. Rancangan penelitian yang digunakan dalam penelitian ini adalah konklusif. Jenis rancangan riset pada penelitian ini adalah rancangan riset kausal yang bertujuan untuk mendapatkan bukti hubungan sebabakibat antara variabel bebas yaitu green product dan green price terhadap variabel terikat minat beli konsumen. Populasi dalam penelitian ini adalah mahasiswa Universitas Islam Lamongan yang berjumlah 4893. Teknik sampling yang digunakan 


\section{Mandalika Mathematics and Education Journal}

dalam penelitian ini adalah teknik nonprobability sampling. Pengambilan sampelnya menggunakan teknik purposive sampling pada mahasiswa Manajemen Fakultas Ekonomi Universitas Islam Lamongan. Ditentukan jumlah sampel yang dijadikan responden dalam penelitian ini sebanyak 100 orang.

Pada penelitian ini terdapat tiga variabel yaitu dua variabel bebas dan satu variabel terikat. Variabel bebas $(X)$ dalam penelitian ini adalah green product $\left(X_{1}\right)$ dan green Place $\left(X_{2}\right)$. Menurut (Rita, 2017) green product adalah komponen internal green marketing yang meliputi tentang bagaimana produk-produk yang dihasilkan oleh perusahaan menjawab berbagai masalah yang dihadapi lingkungan secara makro, misalnya sampah, polusi, lapisan ozon, pemanasan global, nutrisi, dan kesehatan sehingga perusahaan dapat menghasilkan produk yang bisa didaur ulang, hemat energy, non-CFC, non kolestrol. Pada produk yang ramah lingkungan, banyak konsumen menganggap bahwa green product memiliki nilai dan manfaat yang baik bagi dirinya dan lingkungan karena berasal dari bahan-bahan yang alami. Untuk alasan tersebut, konsumen green product menganggap bahwa uang yang dikeluarkan sebanding dengan manfaat yang diterima. Konsumen mulai mencari kesempatan untuk mengurangi dampak lingkungan terhadap pembeliannya dengan membeli green product. Variabel terikat $(Y)$ dalam penelitian ini adalah minat beli konsumen. Minat beli menurut Abdullah, Thamrin (2003) adalah bagian dari komponen perilaku konsumen dalam sikap mengkonsumsi, kecenderungan responden untuk bertindak sebelum keputusan membeli benar-benar dilaksanakan. Indikator green product menurut Junaedi (2005) adalah (1) prodak yang tidak berbahaya bagi manusia dan lingkungannya, (2) tidak boros sumberdaya, (3) tidak menghasilkan sampah berlebihan, (4) Tidak melibatkan kekejaman pada binatang. Sedangkan indikator minat beli konsumen menurut Schiffman dan Kanuk (2004) adalah (1) kesadaran akan kebutuhan, (2) Pengenalan produk, (3) Evaluasi alternatif. Teknik pengumpulan data yang digunakan dalam penelitian iniadalah angket dan obsevasi. Angket disebarkan pada 100 mahasiswa yang berisi tentang item-item pertanyaan tentang variabel penelitian. Semua angket yang disebarkan pada 100 responden kembali dengan jumlah yang sama 100. Jenis angket pada penelitian ini bersifat tertutup, dimana setiap butir pernyataan telah disediakan jawabannya sehingga responden hanya memilih jawaban yang telah tersedia. Sedangkan kegiatan observasi digunakan untuk mendapatkan gambaran permasalahan yang dibutuhkan dalam penelitian ini. Skala pengukuran yang digunakan adalah skala likert. Skala likert adalah skala pengukuran dengan lima kategori respon yang berkisar antara "sangat setuju" hingga "sangat tidak setuju" yang mengharuskan responden menentukan derajat persetujuan atau ketidaksetujuan mereka terhadap masing-masing dari serangkaian pernyataan mengenai objek stimulus Malhotra (2005). Dalam penelitian ini penulis menggunakan skor 1 hingga 5. Adapun skor yang diberikan dari item adalah sangat setuju skor nilai 5 , setuju skor nilai 4, netral skor nilai 3, tidak setuju skor nilai 2, sangat tidak setuju skor nilai 1.

Teknik analisis data menggunakan analisis regresi linear berganda. Setelah melalui uji validitas instrumen, reliabilitas instrumen dan uji asumsi klasik. Uji asumsi klasik yang digunakan yakni uji normalitas residual dengan menggunakan uji Kolmogorov-Smirnov dan uji heteroskedastisitas dengan menggunakan scaterplot dan uji glejser. 


\section{HASIL DAN PEMBAHASAN}

Sebelum melakukan proses analisis data, peneliti melakukan tes pada instrumen penelitian yang digunakan dengan uji validitas instrumen dan uji reliabilitas instrumen. Uji validitas instrumen green product dan minat beli konsumen tidak terdapat butir soal yang gugur. Hal ini dibuktikan dengan nilai probabilitas setiap butir soal signifikan, dengan semua nilai butir soal $p$-value $<0,05$ dan juga nilai $r$ hitung lebih besar dari nilai $r$-tabel $(0,2006)$. Hal ini menunjukkan bahwa indikator dari masing-masing variabel dinyatakan valid atau dapat mengukur variabel-variabel tersebut dengan tepat. Setelah melalui uji reliabilitas, diketahui bahwa nilai cronbanch's alpha untuk variabel green product sebesar 0,817 variabel green price sebesar 0,738 dan variabel minat beli konsumen sebesar 0,780. Besarnya nilai reliabilitas lebih besar dari alpha minimum yaitu $(\alpha=0,60)$, berdasarkan pendapat Ety Rochaety (2007) maka dapat disimpulkan bahwa instrumen green product dan minat beli konsumen tersebut reliabel.

Penelitian ini menggunakan analisis regresi linear beganda untuk melihat adanya pengaruh antara green product dan green price terhadap minat beli mahasiswa unisla terhadap produk tupperware. Sebelum melakukan pengujian dengan menggunakan regresi linear berganda, dilakukan uji asumsi klasik. Berdasarkan hasil analisis dengan menggunakan grafik normal plot didapatkan hasil bahwa titik-titik menyebar di sekitar garis diagonalnya dan mengikuti arah garis diagonalnya, hal ini menunjukkan distribusi menunjukkan distribusi residual normal. Hal ini juga di dukung berdasarkan uji Kolmogorov-Smirnov yang menunjukkan nilai signifikansi Kolmogorof-Smirnov yaitu lebih besar dari 0,05 yaitu sebesar 0,293. Dengan demikian penelitian ini dikatakan berdistribusi normal. Selain itu hasil dari uji glejser menunjukkan bahwa semua nilai signifikansi pada setiap variabel lebih dari 0,05 yaitu sebesar 0,073 dan 0,123. Sehingga dapat disimpulkan bahwa dalam model regresi tidak terjadi heteroskedastisitas. Hal tersebut didukung dengan gambar scaterplot bahwa titik data menyebar diatas dan dibawah nilai 0 yang berarti bahwa model regresi tidak terjadi heteroskedastisitas. Seperti pada gambar di bawah ini. 


\section{Mandalika Mathematics and Education Journal}

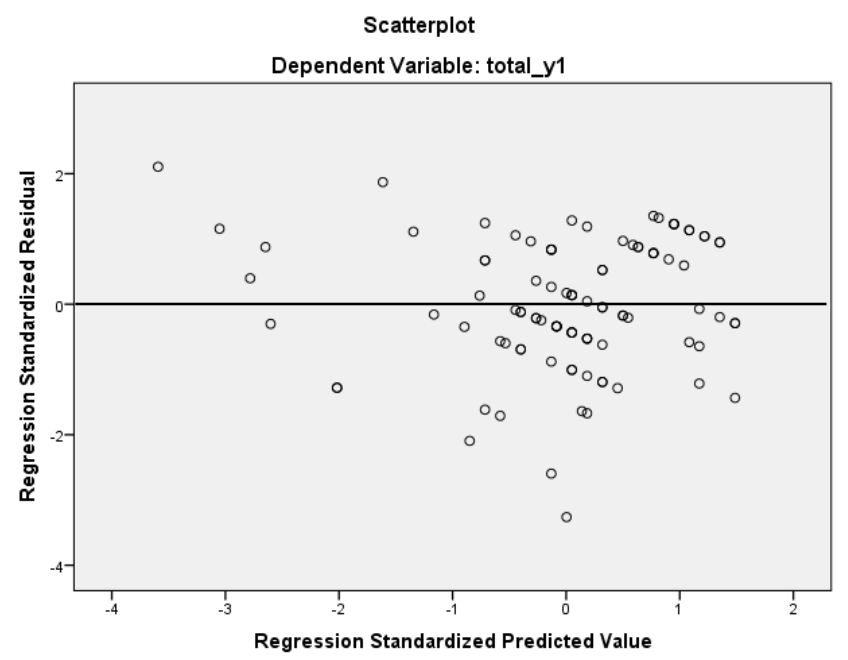

Gambar 1. Scaterplot Heteroskedastisitas

Berdasarkan karakteristik demografi responden, dari 100 mahasiswa sebanyak 68 responden berjenis kelamin perempuan dan 32 responden berjenis kelamin laki-laki. Responden berusia rata-rata 21 tahun. Responden merupakan mahasiswa aktif yang sebagian kecil sebanyak 35\% berkuliah dan bekerja. Hasil dari analisis regresi linear berganda yaitu sebagai berikut:

Tabel 1. Hasil Analisis Regresi Linear Berganda

\begin{tabular}{llc}
\hline \multicolumn{1}{c}{ Keterangan } & \multicolumn{1}{c}{ Nilai } & Sig. \\
Konstanta (a) & 2,997 & 0,039 \\
Koefisien Regresi $\left(b_{1}\right)$ & 0,548 & \\
Koefisien Regresi $\left(b_{2}\right)$ & 0,164 & \\
$t_{\text {hitung1 }}$ & 6,280 & 0,000 \\
thitung2 $_{\text {F }}$ & 1,612 & 0,110 \\
$\mathrm{~F}_{\text {hitung }}$ & 23,810 & 0,000 \\
$\mathrm{R}$ Square & 0,269 & \\
\hline
\end{tabular}

Sumber: Output SPSS

Dari tabel 1 di atas, di peroleh persamaan regresi sebagai berikut:

$$
Y=2,997+0,548 X_{1}+0,164 X_{2}
$$

Keterangan:

$Y=$ Minat beli konsumen

$X_{1}=$ Green Product

$X_{2}=$ Green price

berdasarkan tabel 1 di atas dapat dilihat bahwa nilai $t_{\text {hitung }}$ variabel green product $\left(X_{1}\right)$ sebesar 6,280 dengan nilai probabilitas signifikan yaitu $0,000<0,05$. Dapat dikatakan bahwa green product berpengaruh secara parsial terhadap minat beli konsumen. Sedangkan untuk variabel green price $\left(X_{2}\right)$ nilai $t_{\text {hitung }}$ sebesar 1,612 dengan nilai probabilitasnya sebesar $0.110>0.05$. jika ditinjau dari nilai t hitung dan t tabel diperoleh 


\section{Mandalika Mathematics and Education Journal}

Volume 2 Nomor 1, Juni 2020

e-ISSN 2715-1190 | | p-ISSN 2715-8292

DOI: http://dx.doi.org/10.29303/mandalika.v2i1.1751

bahwa nilai t hitung $1,612<1,661$ sehingga menolak $H_{0}$ dengan kata lain dapat dikatakan bahwa tidak ada pengaruh secara parsial antara variabel green price $\left(X_{2}\right)$ terhadap minat beli konsumen. Namun jika ditinjau dari pengaruh secara simultan antara green product $\left(X_{1}\right)$ dan green price $\left(X_{2}\right)$ terhadap minat beli konsumen terdapat pengaruh yang sangat signifikan. Hal ini ditinjau dari nilai $F_{\text {hitung }}$ sebesar 23,810 lebih besar daripada F tabelnya yaitu sebesar 3,09. Ditinjau dari nilai probabilitas $\mathrm{F}$ hitung yaitu $0,000<0,05$. Karena kedua nilai $t_{\text {hitung }}$ positif, maka pengaruhnya positif, yaitu jika green product dan green price semakin kuat, maka minat beli konsumen juga akan semakin kuat. Dengan kata lain jika nilai green product dinaikkan sebesar 1 satuan maka minat beli konsumen juga akan ikut naik sebesar 0,548 dan apabila green price dinaikkan sebesar 1 satuan pula maka minat beli konsumen juga akan naik sebesar 0,164 . Sehingga dapat disimpulkan bahwa green product dan green price secara simultan berpengaruh positif terhadap minat beli konsumen. Hasil nilai koefisien determinasi $\left(R^{2}\right)$ sebesar 0,332 , artinya green product dan green price berkontribusi mempengaruhi minat beli konsumen sebesar 33,2\% sedangkan sisanya sebesar $66,8 \%$ dipengaruhi oleh variabel lain di luar variabel yang diteliti oleh peneliti.

Hal tersebut menunjukkan bahwa green product berkaitan dengan kegiatan menjual produk tupperware memberikan kontribusi terhadap terciptanya minat beli konsumen. Hal ini di dukung oleh penelitian yang dilakukan oleh Almuarief (2016) bahwa green marketing secara signifikan berpengaruh positif terhadap minat beli konsumen yang dimediasi oleh brand image pada studi kasus air minum dalam kemasan Ades. Proses keputusan konsumen menurut pendapat Sumarwan (2010) dipengaruhi oleh tiga faktor utama, yaitu strategi pemasaran perbedaan individu dan faktor lingkungan. Sehingga bentuk strategi pemasaran seperti halnya kegiatan green product dapat menarik minat beli konsumen dalam memilih produk yang diinginkan oleh konsumen sebelum melakukan keputusan pembelian.

Hasil analisis regresi linear berganda menunjukkan hasil nilai konstanta (a) sebesar 2,997 yang berarti bahwa apabila variabel green product bernilai 0 (nol), maka minat beli konsumen bernilai positif, yaitu sebesar 2,997 satuan. Artinya tanpa melihat aspek-aspek yang unggul dalam kegiatan green product dan green price, minat beli konsumen pada produk tupperware sudah cukup tinggi. tingginya hasil tersebut dikarenakan oleh faktorfaktor lain seperti bentuknya yang unik, menarik, kualitas plastiknya yang kedap udara sehingga membuat tupperware menjadi primadona untuk dijadikan tempat atau wadah bekal untuk anak ataupun tempat menyimpan makanan lainnya agar tidak basi tanpa mempertimbangkan produk tersebut ramah lingkungan ataupun tidak meskipun harga tupperware tergolong tidak murah namun peminatnya tetap berlimpah. Hal tersebut terlihat pada analisis secara parsial terhadap green price yang mana tidak ada pengaruh terhadap minat beli kinsumen tupperware.

Selain itu kegiatan promiso yang digencarkan oleh tupperware baik melalui media maupun melalui ajang pemberian harga khusus untuk mamber menjadikan produk ini primadona bagi para ibu-ibu untuk berlomba-lomba memulai usaha melalui tupperware ini mampu menjadi minat beli konsumen pada produk tupperware ini. Penyebab lain yang menjadi minat beli pada konsumen dalam penelitian ini disebabkan oleh 


\section{Mandalika Mathematics and Education Journal \\ Volume 2 Nomor 1, Juni 2020 \\ e-ISSN 2715-1190 | | p-ISSN 2715-8292 \\ DOI: http://dx.doi.org/10.29303/mandalika.v2i1.1751}

keunggulan-keunggulan yang dimiliki oleh tupperware dibandingkan produk lain. Keunggulan-keunggulan yang dimiliki tupperware diantaranya bahan yang digunakan terbuat dari plastik yang tebal dan kokoh, tutup wadah rekat dan kedap udara, garansi yang diberikn seumur hidup, menyerap bau makanan, warna yang digunakan menarik. Keunikan yang dimiliki oleh produk tupperware ini yakni riskan digigit tikus sehingga wadah-wadah yang kita pakai untuk makanan tidak akan terkontaminasi oleh hewan liar jika sembarangan disimpan.

\section{PENUTUP}

Berdasarkan pembahasan dari hasil analisis dapat disimpulkan bahwa variabel green product dan green price pada produk Tuperware secara simultan berpengaruh positif dan signifikan terhadap minat beli konsumen (studi kasus pada mahasiswa Manajemen Fakultas Ekonomi Universitas Islam Lamongan). Model matematika diperoleh $Y=2,997+0,548 X_{1}+0,164 X_{2}$ sebagai representasi pengaruh green product dan green price terhadap minat beli konsumen pada produk Tupperware. Namun secara parsial hanya variabel green product saja yang berpengaruh terhadap minat beli konsumen produk tupperware. Sehingga variabel green product yang berpengaruh paling dominan terhadap minat beli konsumen produk tupperware khususnya mahasiswa manajemen Universitas Islam Lamongan. Variabel green product dan green price berkontribusi dalam mempengaruhi minat beli sebesar $33,2 \%$ sedangkan sisanya sebesar $66,8 \%$ dipengaruhi oleh variabel lain di luar variabel yang diteliti oleh peneliti

Berdasarkan hasil penelitian diatas, maka dapat dikemukakan beberapa saran bagi penelitian selanjutnya yakni indikator dalam variable green product dan green price dalam penenlitian ini masih kurang spesifik, disarankan agar penelitian selanjutnya untuk menambah referensi mengenai indikator variabel green product dan green price baik dari jurnal-jurnal penelitian ataupun literatur lain untuk lebih memberi pemahaman terkait variabel green marketing.

Pengembangan beberapa item yang lain dari variabel strategi pemasaran yang menggunakan isu-isu lingkungan seperti green place, green promotion dan yang lainnya agar penelitian tentang green marketing dapat diketahui dengan detil green marketing mana yang berpengaruh paling dominan terhadap perilaku konsumen salah satunya minat beli konsumen terhadap sebuah produk.

\section{REFERENSI}

Abdullah, Thamrin (2003), Manajemen Produksi dan Industri Kecil. Jakarta: Pusat Penerbitan Universitas Terbuka.

Almuarif. (2016). Pengaruh Green Marketing terhadap Minat Beli yang Dimediasi oleh Brand Image (Studi pada Air Minum dalam Kemasan Ades). Skripsi: Universitas Negeri Yogyakarta.

Dahlstrom, Robert. (2011). GreenMarketing Management.Canada: Nelson Education. Ltd.

Ety, Rochaety dan Ratih Tresnati, Latief, 2007. Metodologi Penelitian Bisnis dengan aplikasi SPSS. Jakarta : Mitra Wacana Media. 


\section{Mandalika Mathematics and Education Journal \\ Volume 2 Nomor 1, Juni 2020 \\ e-ISSN 2715-1190 | | p-ISSN 2715-8292 \\ DOI: http://dx.doi.org/10.29303/mandalika.v2i1.1751}

Haryadi, Rudi. (2009). Pengaruh strategi green marketingterhadap pilihan konsumen melalui pendekatan marketing mix (Studi kasus pada The Body Shop Jakarta). Thesis. Program Studi Magister Management-Program Pascasarjana Universitas Diponegoro.

Junaedi, S.M.F. (2005). Pengaruh Kesadaran Lingkungan pada Niat Beli Produk Hijau: Studi Perilaku Konsumen Berwawasan Lingkungan. Jurnal Manajemen dan Bisnis, 9(2), hal 189201.

Malhotra, Naresh K. (2005). Riset Pemasaran Pendekatan Terapan Ed. 4 Jilid 1. Jakarta :Indeks.

Polonsky, M.J., \&amp; Rosenberger, P.J. (2001). Reevaluating Green Marketing: A Strategic Approach. Business Horizons, 44(5), 21-30.

Rita. (2017). Green Marketing. Fakultas Marketing International: Binus University Bussiness School. (http://bbs.binus.ac.id/international-marketing/2017/05/green-marketing/: diakses pada tanggal 26 Oktober $2019: 05.57 \mathrm{WIB})$

Schiffmandan Kanuk. 2004. Perilaku Konsumen.Edisi 7. Prentice Hall. Jakarta.

Sumarwan, Ujang.(2010). Perilaku Konsumen-Teori dan Penerapannya dalam Pemasaran. Bogor: Gralia Indonesia. 